\title{
Türkiye'deki Müşterilerin Akıllı Şebekelerde Yük Kaydırmaya Dayalı Talep Tarafı Yönetimine Tepkileri
}

\author{
Recep ÇAKMAK ${ }^{*}$, İsmail Hakkı ALTAŞ²
}

\section{Öz}

Akıllı şebeke üzerine teknik çalışmalar tüm dünyada ve Türkiye’de devam etmektedir. Akıllı şebekeleri geleneksel şebekelerden ayıran en önemli özelliklerden birisi, akıllı şebekelerin dağıtık üretim yapısına sahip olmasıdır. Bu nedenle talep tarafı yönetimi günümüzün dağıtım şebekelerinde öne çıkan araştırma konularından biridir. Geleneksel şebekelerdeki “tüketime göre üretim” yaklaşımı yerine akıllı şebekelerde, talep tarafı yönetimi ile "üretime göre tüketim” yaklaşımı benimsenmektedir. Akıllı şebeke ve talep tarafı yönetimi üzerine teknik ve akademik çalışmalar yapılırken, akıllı şebekelerin uygulama safhasında önemli paydaşlarından biri olan tüketicilerin akıllı şebekelere ve talep tarafı yönetimine ilişkin tutumlarının araştırılması önem arz etmektedir. Bu çalışmada, Türkiye'deki müşterilerin akıllı şebekelerde yük kaydırmaya dayalı talep tarafı yönetimine yönelik tepkileri ve tutumları, İstanbul'da gerçekleştirilen bir kamuoyu araştırmasının (anket) sonuçları kullanılarak sunulmuştur. Sunulan sonuçlar, anket verilerinin istatistiksel frekans analizine tabi tutulmasıyla elde edilmiştir. Elde edilen bulgular Türkiye'de akıllı şebeke çalışmalarının ve talep tarafı yönetimi politikalarının geliştirilmesine katkı sağlayacaktır.

Anahtar Kelimeler: Akıllı şebekeler, Anket, Elektrik tüketimi, Elektrik müşterileri, Talep tarafı yönetimi.

\section{The Reactions of Customers in Turkey Towards Load Shifting Based Demand Side Management in Smart Grids}

\begin{abstract}
Technical studies on smart grids have been underway all over the world and in Turkey. One of the most important features that distinguishes the smart grids from conventional electrical grids the distributed generation structure of the smart grids. Therefore, demand side management (DSM) studies are one of the prominent research topics in today's power distribution networks. In the smart grids, "consumption follows generation” paradigm is adopted by means of DSM instead of the "generation follows consumption” paradigm in conventional electrical grids. While progressing technical and academic studies on the smart grid and demand-side management, it is important to investigate the perspective of consumers, who are one of the important stakeholders in the implementation phase of the smart grids. In this study, reactions and attitudes of customers in Turkey towards load shifting based demand side management in the smart grids are presented using results of a public survey, which is implemented in Istanbul. The presented results are obtained through statistical frequency analysis of the public survey data. The findings would contribute to the development of the smart grid studies and demand-side management policies in Turkey.
\end{abstract}

Keywords: Smart grids, Public survey, Electricity consumption, Electricity customers, Demand side management.

\footnotetext{
${ }^{1}$ Gümüşhane Üniversitesi, Mühendislik ve Doğa Bilimleri Fakültesi, Gümüşhane, Türkiye, rcakmak@gumushane.edu.tr

${ }^{2}$ Karadeniz Teknik Üniversitesi, Mühendislik Fakültesi, Trabzon, Türkiye, ihaltas@ktu.edu.tr
}

${ }^{1}$ https://orcid.org/0000-0002-6467-6240 ${ }^{2}$ https://orcid.org/0000-0001-9298-4091 


\section{Giriş}

Yenilenebilir enerji kaynaklarından elektrik üretiminde düşen maliyetler ve yenilenebilir kaynaklardan elektrik üretimi için verilen devlet teşvikleri sonucunda yenilenebilir kaynaklardan elektrik üreten çok sayıda dağıtık üretim birimi elektrik şebekesine dahil olmuştur. Bu durum mevcut elektrik şebekesinin değişim ve dönüşümüne yol açmaktadır. Geleneksel elektrik şebekeleri Şekil 1'de gösterildiği gibi tek yönlü bir veri akışı ve elektrik güç akışı yapısında iken, üretim ve tüketim birimlerinin iç içe olduğu akıllı elektrik şebekelerinin yapısı ise Şekil 2'de gösterildiği gibidir.

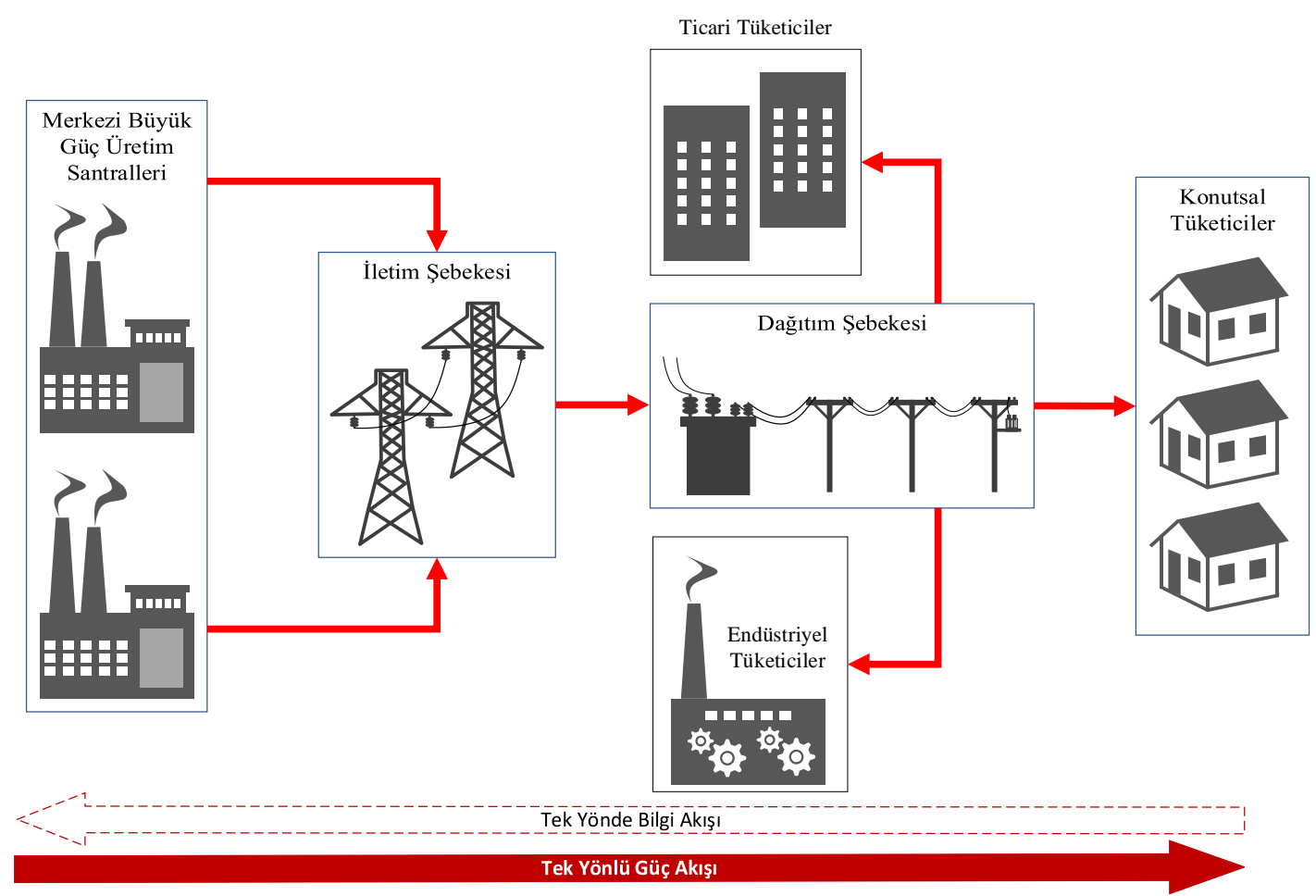

Şekil 1. Geleneksel elektrik şebekesinin temel yapısı ve bileşenleri.

Geleceğin şebekesi olarak ifade edilen, çift yönlü veri ve enerji akışına olanak sağlayan, gelişmiş iletişim ve veri işleme teknolojilerine sahip olan akıllı şebeke sistemlerinde, yenilenebilir güç üretim sistemlerinin bağlantı noktalarında üretilen güçle tüketilen gücün eşleşmesinden kaynaklanan sorunların ve tepe tüketimlerin oluşturduğu sorunların çözümü için uygun maliyetli bir yöntem olarak talep tarafinın yönetimi (TTY) önerilmektedir (Gelazanskas ve Gamage, 2014). 


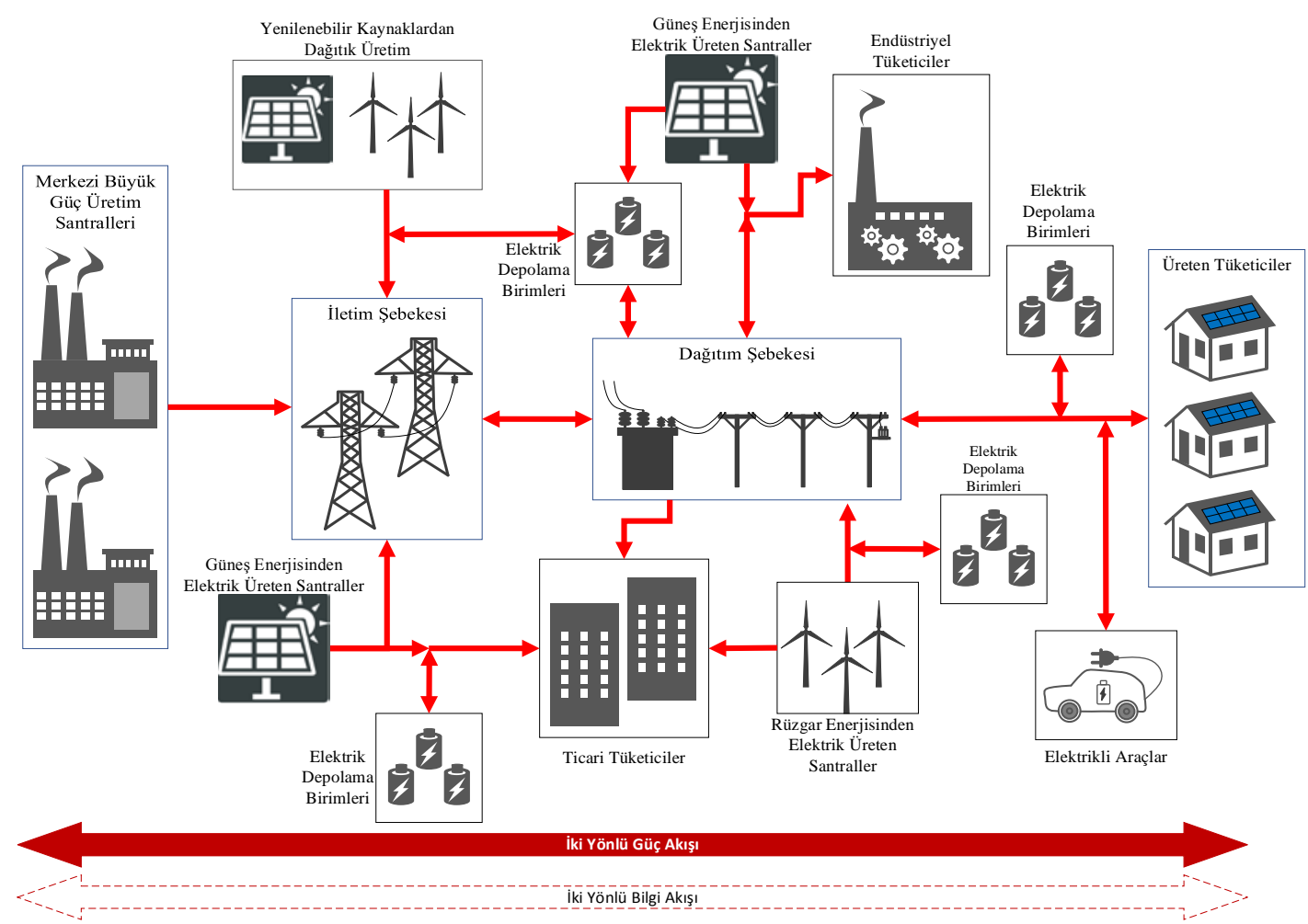

Şekil 2. 21.yy’da oluşmaya başlayan ve dağıtık üretim birimlerinden oluşan akıllı şebeke.

Bugünün şebekesiyle geleceğin akıllı şebekelerinin karşılaştırılması (Wissner, 2011) Tablo 1 'de yer almaktadır.

Tablo 1. Bugünün şebekesiyle geleceğin akıllı şebekelerinin karşılaştırılması.

\begin{tabular}{|c|c|c|}
\hline & Bugünün Elektrik Şebekeleri & Geleceğin Akıllı Şebekeleri \\
\hline Üre & $\begin{array}{l}\text { Üretim, merkezi büyük güç santrallerinde } \\
\text { yapılarak tüketim noktalarına iletilir. }\end{array}$ & $\begin{array}{l}\text { Daha çok yenilenebilir kaynaklardan küçük } \\
\text { ölçekli dağıtık üretim sistemleriyle tüketimin } \\
\text { yakınında yapılır. }\end{array}$ \\
\hline $\begin{array}{l}\text { İletim ve } \\
\text { Yedek Güç }\end{array}$ & $\begin{array}{l}\text { Yedek güç birimleri telefon aracılığıyla } \\
\text { sistem operatörü tarafından talep edilir. }\end{array}$ & $\begin{array}{l}\text { Yedek güç isteği, akıllı sistemler yoluyla } \\
\text { isteklerin otomatik olarak yönlendirildiği geniş } \\
\text { bant bağlantısı üzerinden yapılır. }\end{array}$ \\
\hline Dağ & $\begin{array}{l}\text { Tüketime göre üretim yapılan ve tek yönlü } \\
\text { güç akışına göre çalışan dağıtım sistemi } \\
\text { vardır. }\end{array}$ & $\begin{array}{l}\text { Üretime göre talebin ayarlandığı, iki yönlü güç } \\
\text { akışının olduğu dağıtım sistemi vardır. }\end{array}$ \\
\hline $\begin{array}{l}\text { Sayaç } \\
\text { Sistemleri }\end{array}$ & $\begin{array}{l}\text { Geleneksel sayaçlar ile tek yönlü bilgi akışı } \\
\text { vardır. }\end{array}$ & $\begin{array}{l}\text { İki yönlü bilgi akışına olanak sağlayan akıllı } \\
\text { sayaçlar vardır. }\end{array}$ \\
\hline Tüke & $\begin{array}{l}\text { Cihazların ve ısıtıcıların kontrolü } \\
\text { tüketiciler tarafından yapılır. }\end{array}$ & $\begin{array}{l}\text { Akıllı cihazların ve ısıtıcıların kontrolü, tüketici } \\
\text { isteklerine göre, otomatik olarak, akıllı } \\
\text { sistemlerle yapılır. }\end{array}$ \\
\hline $\begin{array}{l}\text { Genel } \\
\text { Sistem }\end{array}$ & $\begin{array}{l}\text { Üretimden tüketime doğru sürekli bilgi } \\
\text { akış1 yoktur. }\end{array}$ & $\begin{array}{l}\text { Üretimden tüketime ve tüketimden üretime } \\
\text { doğru sürekli bilgi akışı vardır. }\end{array}$ \\
\hline
\end{tabular}


Değişen ve dönüşen elektrik şebekelerindeki teknik sorunların çözümünün yanı sıra, elektrik üretiminden kaynaklı sera gazı salınımlarını azaltmak ve iklim değişikliği konusundaki kötü gidişi değiştirmek için sera gazı salınımının en kısa sürede azaltılması gerekmektedir. Uluslararası Enerji Ajansı'nın (International Energy Agency-IEA) 2016 raporuna (IEA, 2016) göre, karbon salınımının 2030 yılına kadar hedeflenen seviyeye getirilebilmesi için kullanılan araçlar arasında en büyük pay, yenilenebilir enerji kaynaklarına ve talep tarafının yönetimine düşmektedir.

Gelişen akıllı şebeke teknolojileri, elektrik tüketicilerinin (müşterilerin) tüketimleri hakkında bilgi sahibi olmalarına olanak sağlamanın yanı sıra, tüketimlerinin miktarlarını ve zamanlarını ayarlamalarına da imkân verecektir. Akıllı şebekelerde tüketicilerin aktif olarak sistemin içinde var olmasına imkân sağlayan, tüketicilerin faturalarında tasarruf yapmalarına olanak sağlayan ve elektrik şebekesinin daha verimli işletilmesinde yardım eden bu yapı, talep tarafının yönetimi (TTY) olarak adlandırılmaktadır. TTY konusunda literatürdeki ilk ve temel çalışmalardan biri olan makalede (Gellings, 1985) TTY kavramı, tüketicinin elektrik tüketimini, elektrik tedarikçisinin arzu ettiği yük tüketim eğrisini elde edecek şekilde etkilemek için planlama, uygulama ve izleme etkinlikleri olarak tanımlanmıştır.

TTY’nin nihai amacı, elektrik şebekesinin verimli işletilmesini sağlayabilmek için elektrik tüketicilerinin akıllı şebekede dinamik ve aktif olarak yer bulmasını sağlayan teknolojileri kullanarak, elektrik tüketicilerinin tüketim biçimlerini değiştirmek ve yönetmektir. TTY'nin amaçlarından birisi müşterilerin tüketimlerinin daha verimli olmasını sağlamak, diğeri ise tüketicilerin tüketim zamanlarının ötelenmesini sağlamaktır. Bu iki amaç kısaca enerji verimliliği ve yük kaydırma olarak da ifade edilebilir (Davito ve ark., 2010). Tepe tüketimlerin kontrol edilmesinde, dağıtım şebekesinde gerilimin kontrol edilmesinde ve yenilenebilir enerji kaynaklarının şebekeye bağlantısıyla ortaya çıkacak olan problemlerin çözümünde TTY sistemlerinin etkili bir araç olarak kullanılabileceğine yönelik çok sayıda çalışma bulunmaktadır (Cardell ve Tabors, 1997; Uddin ve ark., 2018; Moura ve De Almeida, 2010; Stadler, 2008; Xu ve Taylor, 2008; Çakmak ve Altaş, 2017). TTY sistemleri akıllı şebekelerin en önemli araçlarından biridir (Davito ve ark., 2010) ve akıllı şebeke çalışmalarında tüketim tarafına yönelik çalışmalara bir eğilim vardır (Verbong ve ark., 2013).

Akıllı talep yönetim sistemleri (ATYS) üzerine literatürde birçok çalışma yapılmış olup, bu sistemlerin en önemli özelliği, tüketicilerin çamaşır makinesi, bulaşık makinesi gibi ötelenebilir cihazlarını, tüketicilerin belirlediği aralıkta şebeke parametreleri veya son tüketiciye sunulan elektrik fiyat kriterine göre otomatik olarak çalıştırılmasıdır. Gelişen bilgi işlem ve haberleşme teknolojilerini kullanan akıllı şebekelerde tüketicilerin ötelenebilir cihazlarının ATYS ile kontrolünü gösteren diyagram Şekil 3’te görülmektedir (Mohsenian-Rad ve ark., 2010; Di Giorgio ve Pimpinella, 2012; Shahnia ve ark., 2012; Altaş ve Çakmak, 2020; Çakmak ve Altaş 2020). 


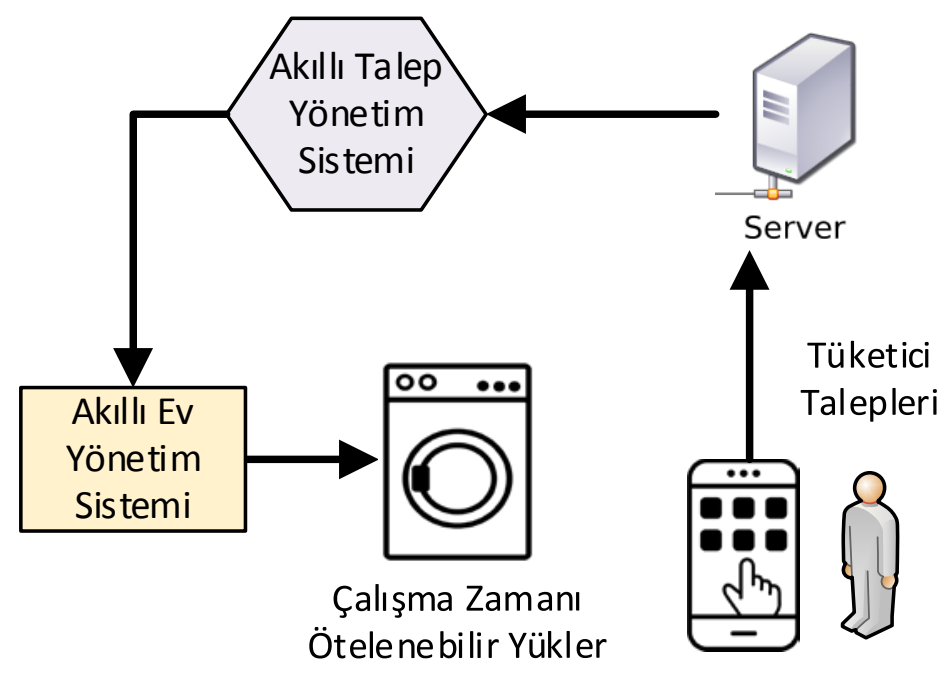

Şekil 3. Akıllı şebekelerde tüketicilerin ötelenebilir cihazlarının ATYS ile kontrolü.

Tüketicilerin ötelenebilir cihazlarının akıllı talep yönetim sistemleriyle talep cevabı programları kapsamında yönetilmesindeki amaç, arzu edilen yük eğrisinin elde edilmesi ve tepe tüketimlerin düşük tüketim bölgelerine kaydırılmasıdır. Böylece tepe tüketimin ortalama tüketime oranı (peak to avarage ratio-PAR) azaltılabilecektir (Liu ve ark., 2014).

Ötelenebilir bir yükün temsili güç tüketimi $\left(P_{\ddot{o}}(t)\right)$ Şekil 4'teki gibi olsun. Bu yük $t_{b a s ̧}$ anında çalışmaya başlamakta ve $t_{\text {bit }}$ anında çalışmasını tamamlamaktadır. Bu bölümde ATYS ile PAR değerinin azaltılmasını açıklamak üzere iki durum ele alınarak irdelenecektir. Birinci durumda bir tüketim bölgesindeki üç tüketici bulunsun ve üç tüketicide de Şekil 4'te güç tüketim eğrisi verilen ötelenebilir yükten bulunsun. Bu yüklerin üçü de $t_{1}$ anında devreye girmiş olsun. Bu durumda bu yüklerin bulunduğu tüketim bölgesindeki güç tüketim eğrisinin Şekil 5’teki gibi olduğu kabul edilsin.

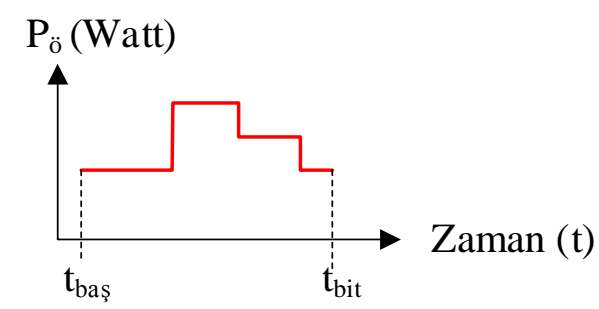

Şekil 4. Ötelenebilir bir yükün temsili güç tüketim eğrisi.

Şekil 5'teki toplam tüketim eğrisinin $\left[\begin{array}{ll}t_{s} & t_{e}\end{array}\right]$ aralığındaki ortalama değeri $P_{\text {ort }}$, maksimum (tepe) değeri $P_{\text {max }}^{\prime}$ olmak üzere, $P A R_{1}$ değeri Denklem (1)'deki gibi hesaplanır.

$$
P A R_{1}=\frac{P_{\text {max }}^{\prime}}{P_{\text {ort }}}
$$




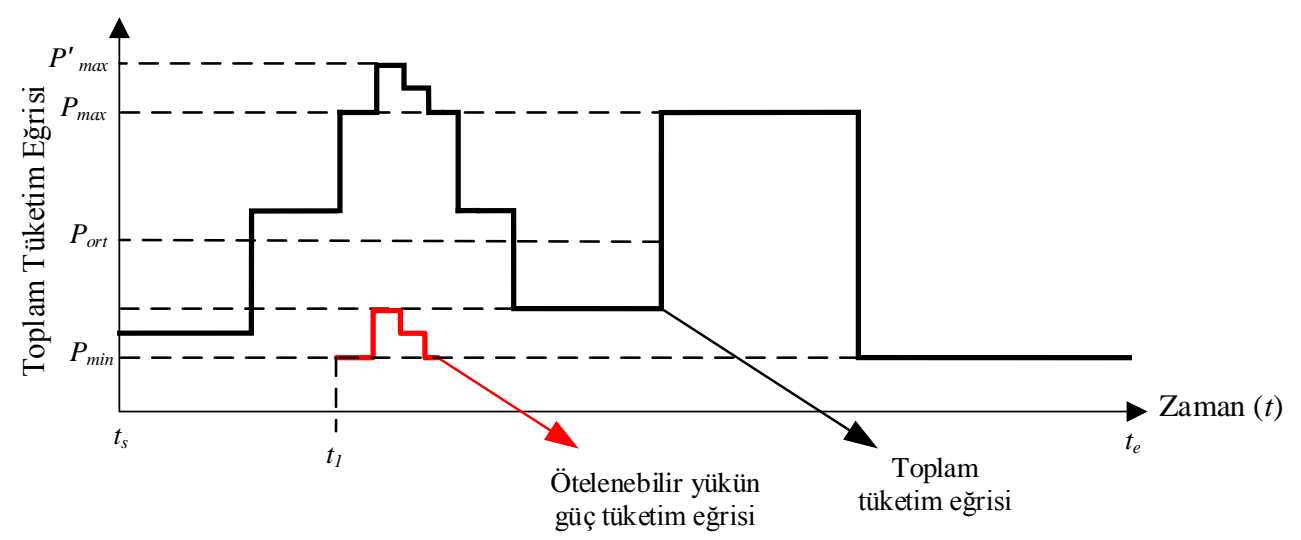

Şekil 5. Birinci durumdaki (ATYS devrede değil) toplam güç tüketim eğrisi.

İkinci durumda, sözü edilen üç tüketici ötelenebilir yüklerine ait çalışma başlangıç alt sınırı $\left(t_{a s}\right)$ ve çalışma bitiş üst sınırı $\left(t_{\text {üs }}\right)$ olan esnek bir zaman aralığı belirlemiş olsunlar. Sistemdeki diğer tüm tüketimler Şekil 4’teki ile aynı olmak üzere, üç tüketicinin ötelenebilir yükleri ATYS tarafından $P A R$ oranını düşürecek biçimde Şekil 6' daki gibi $t_{1}, t_{2}$ ve $t_{3}$ zamanlarında çalıştırılmış olsun.

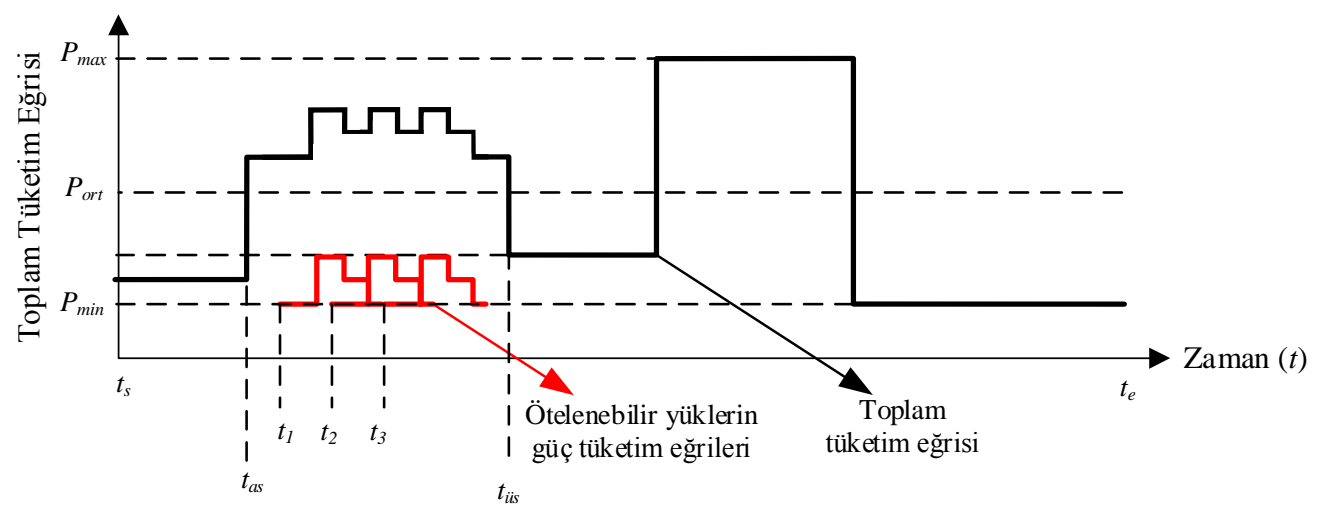

Şekil 6. İkinci durumdaki (ATYS devrede) toplam güç tüketim eğrisi.

ATYS tarafından yapılan planlama neticesinde oluşan toplam güç tüketim eğrisinin yeni tepe değeri $P_{\max }$ olacaktır. ATYS ile tüketicilerin ötelenebilir yüklerinin sadece çalışma zamanı değiştirilmiş olduğundan sistemdeki toplam tüketim miktarı değişmeyecek, $\left[\begin{array}{ll}t_{s} & t_{e}\end{array}\right]$ aralığındaki ortalama tüketim değeri yine $P_{\text {ort }}$ olacaktır. ATYS ile yapılan planlama neticesinde oluşan yeni durum için $P A R_{2}$ değeri Denklem (2) ile aşağıdaki gibi hesaplanabilir.

$P A R_{2}=\frac{P_{\max }}{P_{\text {ort }}}$ 
Şekil 5, Şekil 6, Denklem (1) ve Denklem (2)'den görüleceği üzere, ATYS ile yapılan planlama neticesinde ötelenebilir yüklerin çalışma zamanları yayılarak tepe tüketimin ortalama tüketime oranı $(P A R)$ azalmıştır. Yukarıdaki örnek incelemede her birinde birer ötelenebilir yük olan 3 adet tüketici ele alınmıştır. Sistemde $n$ adet ötelenebilir yük varsa, tüketicinin esnek aralık sunduğu bu ötelenebilir yükler, ATYS tarafından $P A R$ değerini minimum yapmak üzere Denklem (5)’teki amaç fonksiyonunu minimum yapacak şekilde, toplam tüketim eğrisi göz önünde bulundurularak planlanacaktır. $i$. ötelenebilir yükün çalışmaya başladığı zaman $t_{\text {baş }}^{i}$, çalışmasının sona erdiği zaman $t^{i}{ }_{b i t}$ olmak üzere, bu yükün toplam çalışma süresi $t_{{ }^{i}}^{i}$ Denklem (3)’teki gibi olacaktır.

$t_{\zeta s}^{i}=\left(t_{b a s}^{i}-t_{b i t}^{i}\right)$

Toplam tüketim eğrisi $P_{t}$ olan bir tüketim bölgesinde i. ötelenebilir yük için ATYS tarafından planlanan optimum çalışma başlangıç zamanı $x_{i}$ olsun. Bu durumda toplam tüketim eğrisinin yeni değeri $P_{t n}$ Denklem (4) ile hesaplanabilir.

$P_{t n}(t)=P_{t}(t)+\sum_{t=x_{i}}^{t+t_{c s}^{i}}\left(P_{t}(t)+P_{i}(t)\right)$

Her bir yükün planlanması sonucunda $P_{t n}$ değeri son değerini alacaktır. ATYS'nin amac1, ötelenebilir yükleri $T$ periyodu için minimum $P A R$ değerini elde edecek şekilde tüketicinin belirlediği çalışma başlangıç zamanı alt sınırı $t_{a s}$ ve çalışma başlangıç zamanı üst sınırı $t_{\text {üs }}$ aralığında planlamaktır.

$f(t)=\min \left[\sum_{i=1}^{n}\left[\frac{\max \left[P_{t}(t)+\sum_{t=x_{i}}^{t+t_{c s}^{i}}\left(P_{t}(t)+P_{i}(t)\right)\right]}{\frac{1}{T}\left(P_{t}(t)+\sum_{t=x_{i}}^{t+t_{c s}^{i}}\left(P_{t}(t)+P_{i}(t)\right)\right]}\right],\left\{x_{i} \mid x_{i} \leq t_{a s}{ }^{i} \wedge x_{i} \geq t_{u ̈ s}{ }^{i}\right.\right.$

Burada,

$n$ : Toplam ötelenebilir yük sayısı

$P_{i}: i$. ötelenebilir yükün gücü

$P_{t}$ : Toplam tüketim eğrisindeki güç 
$t_{a s}^{i}: i$. ötelenebilir yük için verilen çalışma başlangıç zamanı alt sınırı

$t_{\ddot{u} s}^{i}: i$. ötelenebilir yük için verilen çalışma başlangıç zamanı üst sınırı

$t_{\zeta_{s}}^{i}: i$. ötelenebilir yükün çalışma süresi

Görüleceği üzere, Denklem (5)’teki amaç fonksiyonunu minimum yapmak üzere çözülmesi gereken problem, bir optimizasyon problemidir. Bu optimizasyon probleminde, toplam ötelenebilir yük sayısı $n$ ve tüketicilerin ötelenebilir yükleri için belirledikleri esnek çalışma aralığı $\left(t_{\ddot{u} s}{ }^{i}-t_{a s}{ }^{i}\right)$ ne kadar fazla olursa, olası çözüm sayısı artacağından dolayı amaç fonksiyonunu minimum yapmak o kadar kolay olacaktır. Bu nedenle, TTY yönetimi çalışmalarında talep cevabı programlarının oluşturulması, uygulanması ve alt yapısının sağlanması kadar, bu programlara katılacak olan tüketicilerin sayısı ve ötelenebilir yükleri için sağlayacakları esneklik de önemli bir konudur.

Akıllı şebekelere ve TTY'ye tüketicilerin bakış açısını ölçmek ve TTY'ye katılıma etki eden faktörleri belirlemek için literatürde birçok anket çalışması yapılmıştır (Mert ve ark, 2008; Oseni ve ark., 2013; Spence ve ark., 2015; Mert ve Tritthart, 2009; Park ve ark., 2017; Back ve ark., 2011). Akıllı cihazların şebeke operatörü tarafından işletilmesinin kullanıcı tarafından kabul edilebilirliğini ve tüketicilerin alışkanlıklarını değiştirmeye istekli olup olmadıklarını tespit ederek analiz etmek için Avrupa'daki beş ülkede (Avusturya, Almanya, İtalya, Slovenya ve İngiltere) toplam 2907 kişiye bir anket uygulanmıştır (Mert ve ark, 2008; Mert ve Tritthart, 2009). Bu çalışmada özellikle tüketicilerin ötelenebilir yüklerinin akıllı cihazlar yoluyla şebeke tarafından kontrol edilmesine yönelik bakışlarını tespit etmek ve ötelenebilir yüklerini ne kadar öteleyebileceklerine ait veri elde etmek amaçlanmıştır.

Tüketicilerin elektrik tüketim davranışlarını ve akıllı sayaçlara yönelik tutumlarını ölçek için 2013 yılında İngiltere'de yapılan anket çalışmasında (Oseni ve ark., 2013), 18 yaş üstü kişilerin tutumlarına yönelik cinsiyet, gelir durumu, eğitim durumu gibi demografik sorular, ölçülen tüketim verilerinin kaydedilmesine karşı tutumlarına yönelik sorular, elektrik tüketim alışkanlıklarını değiştirmede etkili olan faktörleri belirlemeye yönelik sorular, elektrikli cihazlarının uzaktan otomatik olarak kontrol edilmesine yönelik tutumlarını ölçen sorular ve elektrik tüketim alışkanlıklarını belirlemeye yönelik sorular sorulmuştur. Anket sonuçları istatistiksel frekans analizine tabi tutularak değerlendirilmiştir. Elde edilen sonuçlara göre 2006, 2008 ve 2010 yıllarında aynı konuda yapılan araştırmaya göre ölçülen tüketim bilgilerinin kaydedilmesini kabul eden katılımcıların oranı artmış olsa da gizlilik konusunun hala büyük bir endişe kaynağı olmaya devam ettiği tespit edilmiştir. Ankete katılanların yarıdan fazlası, enerji sağlayıcıları tarafından akıllı sayaçlar aracılığıyla ayrıntılı ölçülen tüketim bilgilerinin kaydedilmesini kabul ederken, verilerinin üçüncü şahıslar tarafından erişilebilir olmasına karşı endişe duyduklarını belirtmişlerdir. Söz konusu çalışmada akıllı cihazların kullanımı yoluyla isteğe bağlı elektrik yüklerini tepe tüketim bölgelerinden kaydırmaya yönelik önemli bir potansiyelin var olduğu tespit edilmiştir. Bununla birlikte, cihazların 
ihtiyaç duyulduğunda kullanılamama durumu ve kişisel kullanım verilerinin mahremiyeti tüketicilerin duyduğu başlıca endişeler arasında yer almıştır. Araştırma sonuçlarına göre tüketicilerin tüketimlerini değiştirmede en etkili olan faktörün ekonomik unsurlar, yani elektrik fiyatı olduğu tespit edilmiştir. Ayrıca talep tarafı yönetimine katılımın fazla olması için tüketicilerin konfor seviyelerinin en az etkilenmesi ve mahremiyet konularında tüketicilerin tatmin edilmesi gerektiği ortaya çıkmıştır. Talep tarafı yönetiminin kamuoyu algısını ölçmek ve tüketicilerin daha akıllı bir enerji geleceğine yönelik tutumlarını tespit etmek üzere İngiltere' de 2441 kişiye çevrimiçi yapılan bir başka anket çalışmasında (Spence ve ark., 2015) çamaşır makinesinin tüketicinin belirleyeceği bir zamanda bitecek şekilde ayarlanıp, talep tarafı yönetim sistemi tarafından otomatik olarak çalıştırılması konusuna tüketicilerin \%50’ye yakınının olumlu tutum sergilediği ortaya çıkmıştır.

Akıllı şebekelerin tüketici tarafından kabul edilebilirliği ve tüketicilerin bu teknolojiyi benimsemelerine yönelik tutumlarını ölçmek üzere Finlandiya ve İsveç’te yapılan bir çalışmada (Back ve ark., 2011), tüketicilerin \%80'e yakınının ekonomik bir karşılık alması durumunda tüketimlerinin izlenmesine ve kaydedilmesine olumlu baktığı görülmüştür. Anket sonuçlarına göre çamaşır makinesi ve bulaşık makinesi gibi yüklerin talep tarafı yönetiminde kullanılmasına tüketicilerin genel bakışının olumlu olduğu tespit edilmiş, buzdolabı ve derin dondurucu gibi yüklerin talep tarafı yönetiminde kullanım potansiyelinin olmadığı ortaya çıkmıştır.

Yukarıda literatürdeki bazı anket çalışmalarından örnekler ve öne çıkan bazı sonuçlar verilmiştir. Literatürdeki bu anket çalışmalarının yapıldı̆̆ı ülkelerde anketlerden elde edilen sonuçlara göre, tüketicilerin TTY'ye katılımını arttırmak ve yeni çözümler geliştirmek için stratejiler oluşturulmaktadır. Bu bakımdan herhangi bir TTY çalışmasının geliştirilme aşamasında, tüketicilere yönelik anket çalışmasıyla tüketici eğilimlerinin, isteklerinin ve çekincelerinin belirlenmesi önem arz etmektedir. Literatür incelendiğinde, Türkiye'de konutlarda yaşayan tüketicilerin akıllı şebekelerde yük kaydırmaya dayalı talep tarafı yönetimine yönelik tutumlarını ölçen, tüketicilerin ötelenebilir yüklerinin kullanım alışkanlıklarını elde etmeye dönük bir çalışmaya rastlanamamıştır. Literatüre katkı sağlamak üzere yapılan bu çalışma;

- Tüketicilerin akıllı şebeke ve talep tarafı yönetimine yönelik tutumlarını,

- Tüketicilerin elektrik tüketimlerinin analiz edilmesine ve kaydedilmesine yönelik bakışını,

- Tüketicilerin ötelenebilir yüklerinin talep tarafı yönetimi kapsamında kullanılmasına yönelik tutumların1,

- Tüketicilerin ötelenebilir yüklerini akıllı talep yönetim sistemiyle planlamaya yönelik tutumların1,

- Türkiye'deki tüketicilerin çamaşır makinesi, bulaşık makinesi gibi ötelenebilir yüklerini kullanma alışkanlıklarına ait sayısal verileri

elde etmeyi amaçlamaktadır. 


\section{Materyal ve Metot}

Bu çalışmada, Türk tüketicilerin akıllı şebekelerde yük kaydırmaya dayalı talep tarafı yönetimine yönelik tutumlarını ölçmek ve ötelenebilir yüklerini çalıştırma alışkanlıklarını elde edebilmek için yapılan anket sonuçları verilmiştir. Anketler belirli bir konuda kişilere yöneltilen sorulardan elde edilen cevaplara dayalı olarak veri toplama tekniği olup, günümüzde birçok alanda farklı şekillerde kullanılmaktadır. Yüz yüze, telefonla ve posta yoluyla görüşmeye dayanan geleneksel anket türleri olmakla birlikte, bilgisayar destekli olarak internet üzerinden veri toplamaya dayanan anket türleri de mevcuttur (Akalın, 2015). Bu çalışma kapsamında yapılan anket yüz yüze yapılmış olup, araştırma kapsamında 18 yaş ve üzerindeki kişilerin görüşleri esas alınmıştır. Hazırlanmış olan anket sorularının uygulanması için İstanbul ili seçilmiştir. Çünkü İstanbul ili, Türkiye'nin küçük bir özeti olma özelliğine sahiptir. Nitekim, Türkiye'de yapılan siyasi ve yerel seçimlerde İstanbul'da alınan sonuçlar Türkiye geneliyle paralellik göstermektedir. Bu nedenle anket İstanbul özelinde uygulanmıştır. Anketin yapıldığı dönemdeki resmi nüfus verilerine göre İstanbul' da 15 milyon kişi yaşamaktadır ve bunların yaklaşık 12 milyonu 18 yaş ve üzerindeki bireylerden oluşmaktadır. Dolayısıyla anket 12 milyonluk ana kütleye uygulanmalıdır. Fakat anketin uygulanması gereken ana kütlenin tamamına ulaşmak mali ve teknik açıdan çok güç olduğundan, araştırma İstanbul'un Anadolu ve Avrupa yakasındaki en işlek iki alışveriş merkezinde yapılmıştır. Bu kapsamda, anket 01.06.2016-11.07.2016 tarihleri arasında olasılığa dayalı sistematik örnekleme yoluyla (Çilingir ve Yıldız, 2010; Akalın, 2015) seçilen 415 tüketiciye gönüllülük esasına göre uygulanmıştır. İlgili örneklem büyüklüğü hesaplamasında, 0,05 anlamlılık düzeyinde ve 0,05 örneklem hatasında belirtilen 100.000'den büyük evren büyüklüğü için 384 sayısı örneklem için yeterli bulunmaktadır (Altunışık ve ark., 2007). Sistematik örnekleme yoluyla alışveriş merkezine ikinci ve dokuzuncu sırada giren bireyler seçilmiştir. Bireylerin seçiminde dikkate alınan sıra numaraları belirlenirken, torba içerisine atılan ve 1'den 10'a kadar rakamların yazılı olduğu kağıtlar arasından seçim yapılmıştır. Anket doldurulmak istenmediğinde bir sonraki bireye geçilmiştir. Yapılan anket çalışması sonucunda geri dönüş sağlanan 400 adet anket formundan, eksik veya hatalı bulunan 24 adet anket formunun elenmesinden sonra elde edilen 391 anket formundaki veriler bilgisayar ortamına aktarılmıştır.

Anketteki sorularda tüketicilerin akıllı şebekelerde talep tarafı yönetimine yönelik tutumları ve ötelenebilir yüklerini çalıştırma alışkanlıklarına ilişkin verileri elde etmek için sorular özgün olarak bu çalışmada belirlenmiştir, anket soruları bu çalışmaya özeldir. Bununla birlikte, demografik soruların hazırlanmasında (Yıldız, 2017) çalışmasından faydalanılmıştır. Anket sorularının belirlenmesinin ardından 40 kişi üzerinde bir ön test işlemi gerçekleştirilmiştir. Bu ön test işleminde soruların anlaşılabilir olup olmadığı, soruları yanıtlayanların sorulan anket sorularını anlayıp 
anlamadıkları tespit edilerek sorularda gerekli düzenlemeler yapılıp anket sorularına son hali verilmiştir. Tüketicinin akıllı talep yönetimi sistemi (ATYS) hakkında bilgi sahibi olmasını sağlamak için Şekil 7’de verilen "5 adımda akıllı talep yönetim sistemi” adlı bilgilendirme şeması anket formunda soruların öncesine yerleştirilmiştir.

5 Adımda Akllı Talep Kontrol Sistemi

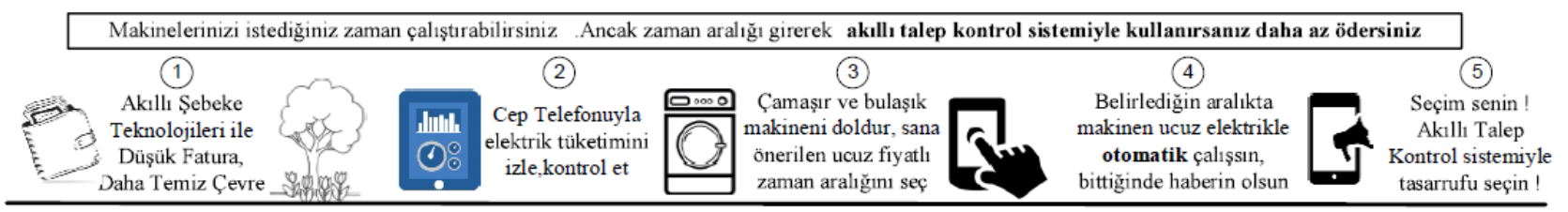

Şekil 7. “Akıllı talep yönetim sistemini anlatan "5 adımda akı1lı talep yönetim sistemi” bilgilendirme şeması.

Anket, üç ana bölümde ölçme ve veri toplamaya yönelik sorulardan oluşturulmuştur. Birinci bölümde ankete katılım sağlayan tüketicilerin demografik özelliklerini belirlemeye yönelik sorular ve tüketicilerin ATYS'den bekledikleri tasarruf oranı sorusu bulunmaktadır. Demografik özellikleri belirlemeye yönelik sorular; cinsiyet, yaş, aylık net gelir, öğrenim durumu, meslek, ev büyüklüğü, ortalama aylık elektrik faturası, evde yaşayan kişi sayısı sorularını içermektedir. Demografik verileri ölçen sorular ve tüketicilerin ATYS'den bekledikleri tasarruf oranına ilişkin soru Tablo 2'de verilmiştir.

Tablo 2. Anketteki demografik sorular ve ATYS ile beklenen tasarruf oranı sorusu.

\begin{tabular}{|c|c|c|}
\hline Cinsiyetiniz? & Öğrenim Durumunuz? & Aylık Ortalama Elektrik Faturanız? \\
\hline ( ) Kadın & ( ) İlköğretim & ( ) 50 TL ve daha az \\
\hline ( ) Erkek & ( ) Lise & ( ) $51-70 \mathrm{TL}$ \\
\hline Yaşınız? & ( ) Önlisans & ( ) $71-90 \mathrm{TL}$ \\
\hline ( ) $18-28$ & ( ) Üniversite & ( ) $91-110 \mathrm{TL}$ \\
\hline ( ) $29-39$ & ( ) Y.Lisans/Doktora & ( ) $111-130 \mathrm{TL}$ \\
\hline ( ) $40-50$ & Mesleğiniz? & ( ) $131-150 \mathrm{TL}$ \\
\hline ( ) $51-61$ & ( ) Serbest meslek & ( ) 151 TL ve üzeri \\
\hline ( ) 62 ve üzeri & ( ) Esnaf & $\begin{array}{l}\begin{array}{l}\text { Yaşadığınız evde } \\
\text { yaşamaktadır? }\end{array} \\
\end{array}$ \\
\hline Aylık Net Geliriniz? & ( ) Memur & ( ) 1 \\
\hline ( ) $1300 \mathrm{TL}$ ve alt1 & ( ) İşşi & ( ) 2 \\
\hline ( ) 1301-2000 TL & ( ) Emekli & ( ) 3 \\
\hline ( ) 2001-3000 TL & ( ) Ev Hanımı & ( ) 4 \\
\hline ( ) 3001-4000 TL & ( ) Öğrenci & () 5 \\
\hline ( ) 4001-5000 TL & ( ) Diğer. & ( ) 6 ve daha fazla \\
\hline ( ) 5001 TL ve üzeri & $\begin{array}{l}\text { Yaşadığınız evin } \\
\text { büyüklüğ̈̈? }\end{array}$ & $\begin{array}{l}\text { ATYS ile beklediğiniz tasarruf } \\
\text { oranı? }\end{array}$ \\
\hline Eviniz kaç odalıdır? & ( ) $80 \mathrm{~m}^{2}$ ve daha az & ( ) \%10 \\
\hline ( ) $1+1$ & ( ) $81-100 \mathrm{~m}^{2}$ & ( ) $\% 11-\% 20$ \\
\hline ( ) $2+1$ & ( ) $101-120 \mathrm{~m}^{2}$ & ( ) $\% 21-\% 30$ \\
\hline ( ) $3+1$ & ( ) $121-140 \mathrm{~m}^{2}$ & ( ) \%31-\%40 \\
\hline ( ) $4+1$ & ( ) $141-160 \mathrm{~m}^{2}$ & ( ) $\% 41$ ve üzeri \\
\hline ( ) 5+1 ve daha fazla & ( ) $161 \mathrm{~m}^{2}$ ve daha fazla & \\
\hline
\end{tabular}


Anketin ikinci bölümündeki sorular, tüketicilerin akıllı şebekelerde yük kaydırmaya dayalı talep tarafının yönetimine ve ATYS ile ötelenebilir yüklerinin kontrolüne ilişkin tutumlarını ölçmeyi amaçlamaktadır. Bu kapsamda hazırlanan 13 adet soru ile ankete katılanlardan, sorulan her bir soruya kendi durumlarına uygun cevap vermeleri istenmiş ve 1: Kesinlikle katılmıyorum, 2: Katılmıyorum, 3: Katılıp katılmama oranım eşit, 4: Katılıyorum, 5: Kesinlikle katılıyorum şeklinde Beşli Likert Ölçeği (Joshi ve ark., 2015) kullanılmıştır. Tüketicilerin akıllı şebekelerde yük kaydırmaya dayalı talep tarafının yönetimine ve ATYS ile ötelenebilir yüklerinin kontrolüne ilişkin tutumlarını ölçen sorular Tablo 3'te yer almaktadir.

Tablo 3. Tüketicilerin akıllı şebekelerde yük kaydırmaya dayalı talep tarafının yönetimine ve ATYS ile ötelenebilir yüklerinin kontrolüne ilişkin tutumlarını ölçmeyi amaçlayan anket soruları

S1: Akıllı elektrik şebekesi kavramını daha önce duydum

S2: Talep tarafi yönetimi kavramını daha önce duydum

S3: Elektrik faturamın daha az gelmesi için elektrik tüketim değerlerimin izlenmesini ve kaydedilmesini isterim

S4: Elektrik faturamı azaltmak için akıllı cihazlar ile yönlendirilmeyi isterim

S5: Düşük fatura ödemek için çamaşır ve bulaşık makinemi elektriğin ucuz olduğu zamanlarda çalıştırmak isterim

S6: Düşük fatura ödemek için çamaşır ve bulaşık makinemin benim belirleyeceğim bir zaman aralığında akıllı kontrol sitemiyle otomatik olarak çalıştırılmasını isterim.

S7: Çamaşır ve bulaşık makinemin otomatik olarak çalıştırılması için makineyi hazır hale getirmek elektrik faturamı azaltacağı için katlanabileceğim bir durumdur.

S8: Çamaşır ve bulaşık makinemi akıllı kontrol sistemiyle planlarsam daha ucuz elektrik fiyatıyla çalışmasını isterim.

S9: Ütü yapacağım zamanı akıllı kontrol sistemiyle planlayarak daha az elektrik faturası ödemeyi tercih ederim.

S10: Elektrik süpürgemi çalıştıracağım zamanı akı1lı kontrol sistemiyle planlayarak daha az fatura ödemeyi tercih ederim.

S11: Ak1ll kontrol sistemini evimde kullanmak isterim.

S12: Akıllı kontrol sistemiyle çalıştıracağım makinelerimi gün öncesi planlama yapabilirim.

S13: Akıllı kontrol sistemiyle çalıştıracağım makinelerimi çalıştırmayı düşündüğüm anda planlama yapmak isterim.

Anketin üçüncü bölümünde, ilk olarak tüketicilerin Tablo 4'te verilen cihazlardan hangilerini ATYS’nin yönlendirmeleriyle kullanmak istediklerine ilişkin seçimlik sorular sorulmuştur.

Tablo 4. Tüketicilerin ATYS'nin yönlendirmeleriyle kullanmak istediği cihazların tespitine yönelik soru

\begin{tabular}{|lc|}
\hline Lütfen Akıllı Kontrol Sisteminin yönlendirmeleriyle kullanmak istediğiniz cihazlart işaretleyiniz. \\
\hline$\square$ Çamaşır Makinesi $\quad \square$ Elektrikli Süpürge $\quad \square$ Ütü \\
\hline$\square$ Bulaşık Makinesi $\quad \square$ Çamaşır Kurutma Makinesi $\square$ Diğer..................... \\
\hline
\end{tabular}


Tüketicilerin çamaşır makinesi, bulaşık makinesi, çamaşır kurutma makinesi, ütü ve elektrikli süpürge gibi yüksek güç tüketimine sahip yüklerinin çalıştırılma zamanlarına ait veri elde etmek için bir günün saatleri dörde bölünerek (06:01-12:00; 12:01-18:00; 18:01-23:59; 00:00-06:00) tüketicilere bu cihazlarını bu zaman dilimlerinin hangisinde/hangilerinde çalıştırdıkları Tablo 5'teki sorular aracılığıyla sorulmuştur.

Tablo 5. Ötelenebilir yüklerin çalıştırılma zamanlarına yönelik veri toplama sorusu

\begin{tabular}{|c|c|c|c|c|c|}
\hline \multirow[b]{2}{*}{ Cihaz Ad1 } & \multicolumn{4}{|c|}{ Genellikle çalıştırdığınız saat aralığı } & \multirow{2}{*}{$\begin{array}{c}\text { Kaç saat } \\
\text { çalışır? }\end{array}$} \\
\hline & $\begin{array}{l}06: 01 \\
12: 00\end{array}$ & $\begin{array}{l}12: 01 \\
18: 00\end{array}$ & $\begin{array}{l}\text { 18:01 } \\
23: 59\end{array}$ & $\begin{array}{l}\text { 00:00 } \\
\text { 06:00 }\end{array}$ & \\
\hline$\square$ Çamaşır Makinesi & $\square$ & $\square$ & $\square$ & $\square$ & \\
\hline$\square$ Bulaşık Makinesi & $\square$ & $\square$ & $\square$ & $\square$ & \\
\hline$\square$ Çamaşır Kurutma Makinesi & $\square$ & $\square$ & $\square$ & $\square$ & \\
\hline$\square$ Ütü & $\square$ & $\square$ & $\square$ & $\square$ & \\
\hline$\square$ Elektrikli Süpürge & $\square$ & $\square$ & $\square$ & $\square$ & \\
\hline
\end{tabular}

Yapılan anket çalışması sonucunda geri dönüş sağlanan anket formundan eksik ve hatalı bulunan 24 adet formun elenmesinden sonra geriye kalan 391 anket formunun verisi bilgisayar ortamına aktarılarak sayısal veri haline getirilmiştir. Elde edilen verilerin değerlendirmesinde verilerin sayısal olarak dağılımlarını belirlemek için, ölçme sonuçlarının görülme sıklığı (frekans) değerlerinden yola çıkarak frekans analizi yapılmıştır.

Anket verilerinin analizi için farklı istatistiksel teknikler kullanılabilir. Aritmetik ortalama ve standart sapma değerlerinin hesabı, istatistikte kullanılan merkezi eğilim ölçülerindendir. Merkezi eğilim ölçüleri hesabı, elde edilen sonuçların verilerin merkezine olan uzaklığı hakkında bilgi verir. $\mathrm{Bu}$ çalışmada Beşli Likert ölçeğinde sorulan sorulara verilen yanıtların her birinin aritmetik ortalaması ve standart sapmaları hesaplanarak, tüketicilerin verdiği cevapların analiz edildiği grafiklerinin yanına yazılmıştır. Beşli Likert ölçeğinde 1: Kesinlikle katılmıyorum, 2: Katılmıyorum, 3: Katılıp katılmama oranım eşit, 4: Katıllyorum, 5: Kesinlikle katıllyorum şeklinde ölçeklendirildiğinden, bir soruya verilen yanıtların ortalamasının 4 civarında olması tüketicilerin ilgili soru hakkındaki görüşünün Katılıyorum'a daha yakın olduğunu gösterir. Aşağıdaki denklemlerde standart sapma ve aritmetik ortalama hesabına ait formüller yer almaktadır. 
$x$ : İlgili soru için Beşli Likert ölçeğinde verilen yanıtların sayısal değerleri (1-5)

$\bar{x}$ : Aritmetik ortalama

ss : Standart sapma

$n$ : Dizideki eleman sayısı

$x_{n}$ :Dizinin $n$. elemanı

olmak üzere;

$x=\left[x_{1} x_{2} \cdots x_{n}\right]$

Aritmetik ortalama Denklem (7) ile hesaplanmıştır.

$\bar{x}=\frac{x_{1}+x_{2}+\cdots+x_{n}}{n}$

Standart sapma(ss) Denklem (8) ile hesaplanmıştır.

$S S=\sqrt{\frac{\left(x_{1}-\bar{x}\right)^{2}+\left(x_{2}-\bar{x}\right)^{2}+\cdots+\left(x_{n}-\bar{x}\right)^{2}}{n-1}}$

\section{Bulgular ve Tartışma}

Ankete katılanların cinsiyete göre dağılımları Şekil 8'deki grafikte verilmiştir. Ankete katılanların \%59,3'ünü kadınlar, \%40,7'sini erkekler oluşturmaktadır. Ankete katılanların demografik özelliklerine ait frekans analizinden elde edilen yüzdelik dağılımları gösteren grafikler ise Şekil 9'da yer almaktadır. Şekil 9'da ayrıca, ankete katılan tüketicilerin ATYS'den bekledikleri tasarruf oranlarına ait frekans analizi sonuçları da yer almaktadır.

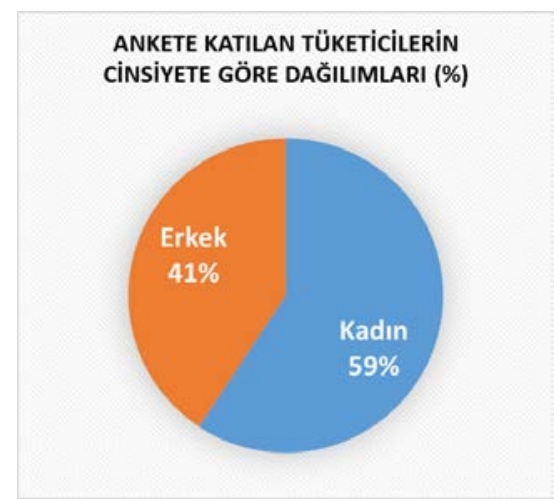

Şekil 8. Ankete katılan tüketicilerin cinsiyete göre dağılımı. 

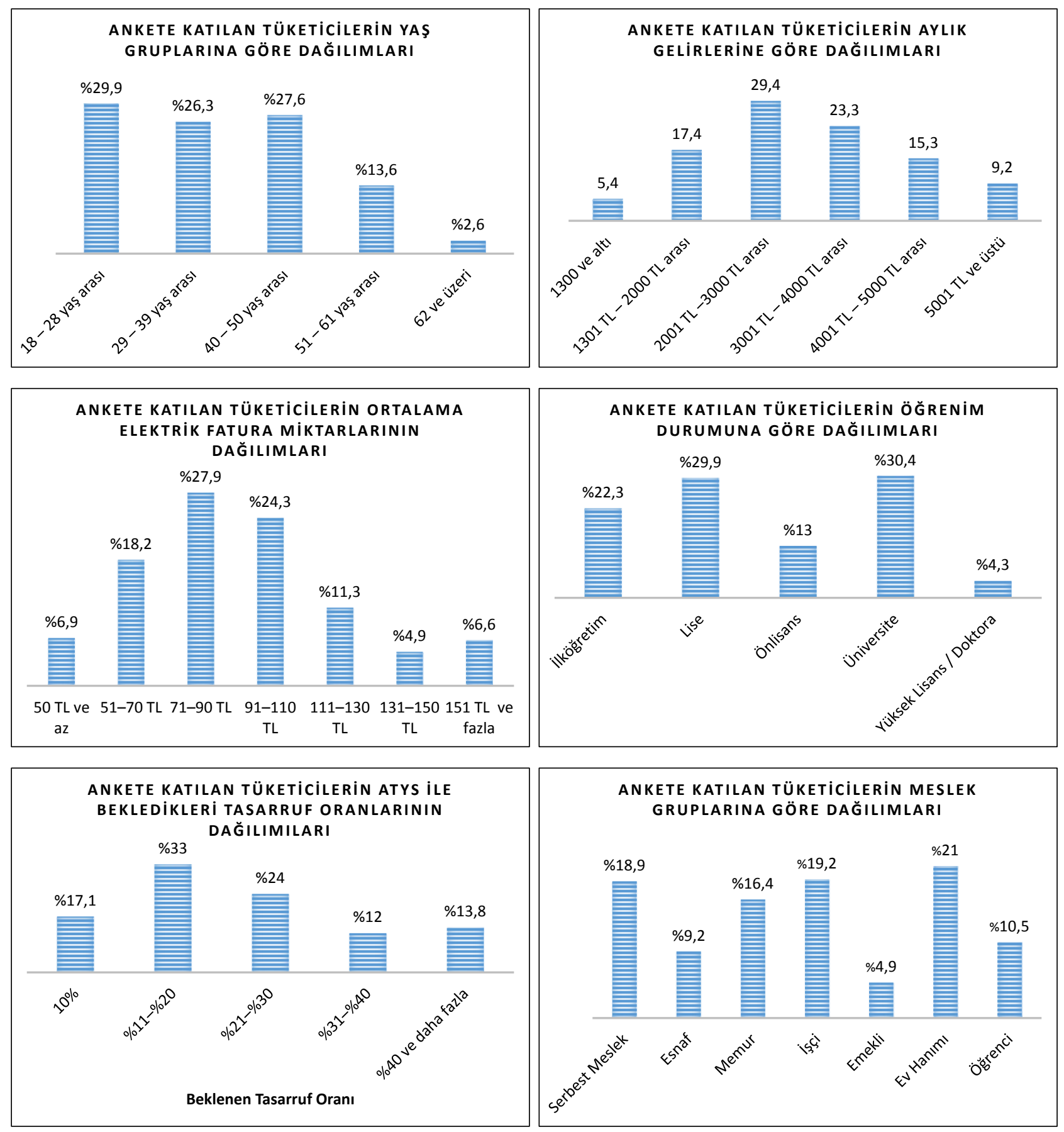

Şekil 9. Ankete katılan tüketicilerin demografik özellikleri ve tüketicilerin ATYS'den bekledikleri tasarruf oran1.

Şekil 9'daki sonuçlardan, tüketicilerin \%33’ünün ATYS ile \%11-\%20 aralığında bir tasarruf beklediği, \%24'ünün ise \%21-\%30 aralığında bir tasarruf beklediği görülmektedir. Ankete katılan tüketicilerin \%13,8'inin \%40'tan fazla tasarruf beklediği görülmüştür. \%10'un altında tasarruf bekleyen tüketicilerin oranı ise \%17,1 olarak tespit edilmiştir.

Ankete katılanların yaş grupları incelendiğinde ankete katılım sağlayarak cevap veren tüketicilerin \%83,8'inin 18 ile 50 yaş aralığında olduğu saptanmıştır. Ankete katılanların meslek dağılımları incelendiğinde, ankete katılanlar arasında en büyük paya \%21 ile ev hanımlarının sahip olduğu görülmektedir. 
Şekil 9’daki demografik verilere sahip katılımcıların, akıllı şebekelerde talep tarafı yönetimi kapsamında akıllı talep yönetim sistemi ile ötelenebilir yüklerinin kontrolüne ilişkin tutumlarını ölçen sorulara verdikleri yanıtların frekans analizleri, yanıtların Beşli Likert ölçeğindeki aritmetik ortalama değerleri ve standart sapmaları Şekil 10 ve Şekil 11'de verilmiştir.

Şekil 10 ve Şekil 11'deki grafikler incelendiğinde “Akıllı Şebeke kavramını daha önce duydum” sorusuna ankete katılanların toplamda \%34’ünün “Katıllyorum” ve “Kesinlikle Katılıyorum” cevaplarını verdiği görülmektedir. Bu soruya "Kesinlikle Katılmıyorum” ve “Katılmıyorum” cevabı verenlerin oranı ise toplamda \%50 olarak tespit edilmiştir. "Talep tarafi yönetimi kavramını daha önce duydum.” sorusuna araştırmaya katılan tüketicilerin yaklaşık \%46'sı “Kesinlikle Katılmıyorum”, \%16’sı ise “Katılmıyorum” yanıtını vermişlerdir. Bu veriler 1şığında, akıllı şebeke ve talep tarafı yönetimi konularının uygulamaya geçirilebilmesi ve tüketicilerin bu teknolojilere daha fazla katılımının sağlanabilmesi için, tüketicilerin akıllı şebekeler ve talep tarafı yönetimi konularında bilgilendirilmesi gerektiği sonucu çıkarılabilir.

"Elektrik faturamın daha az gelmesi için elektrik tüketim değerlerimin izlenmesini ve kaydedilmesini isterim” sorusuna ankete katılan tüketicilerin \%78’inin (\%34 Kattlıyorum, \%44 Kesinlikle Katıllyorum) olumlu bir tutum sergilediği görülmektedir. Benzer şekilde, “Elektrik faturamı azaltmak için akıllı cihazlar ile yönlendirilmeyi isterim” sorusuna cevap veren tüketicilerin \%77’sinin (\%32 Katıllyorum, \%45 Kesinlikle Katılıyorum) olumlu bir tutuma sahip olduğu görülmektedir. "Düşük fatura ödemek için çamaşır ve bulaşık makinemi elektriğin ucuz olduğu zamanlarda çalıştırmak isterim” sorusuna katılımcıların \%82'sinin (\%32 Katıllyorum, \%50 Kesinlikle Katıllyorum) olumlu bir tutuma sahip olduğu görülmektedir.

Tüketicilerin kendi belirleyeceği saat aralıklarında çamaşır ve bulaşık makinelerinin akıllı kontrol sitemiyle otomatik olarak çalıştırılmasına yönelik tutumlarını ölçmek için oluşturulan “Düşük fatura ödemek için çamaşır ve bulaşık makinemin benim belirleyeceğim bir zaman aralığında akıllı kontrol sitemiyle otomatik olarak çalıştırılmasını isterim.” ifadesine katılımcıların 82'sinin (\%32 Katılıyorum, \%50 Kesinlikle Katılıyorum) olumlu baktıkları görülmektedir.

Akıllı talep kontrol sistemiyle çamaşır makinesi ve bulaşık makinesi gibi cihazları kullanabilmek için bu makinelerin önceden hazır hale getirilmesi gerekmektedir. Tüketicilerin bu konu hakkındaki tutumlarını tespit edebilmek için hazırlanan "Çamaşır ve bulaşık makinemin otomatik olarak çalıştırılması için makineyi hazır hale getirmek elektrik faturamı azaltacağı için katlanabileceğim bir durumdur.” ifadesine ankete katılan tüketicilerin \%72'sinin (\%33 Katılıyorum, \%39 Kesinlikle Katılıyorum) olumlu baktıkları tespit edilmiştir. 

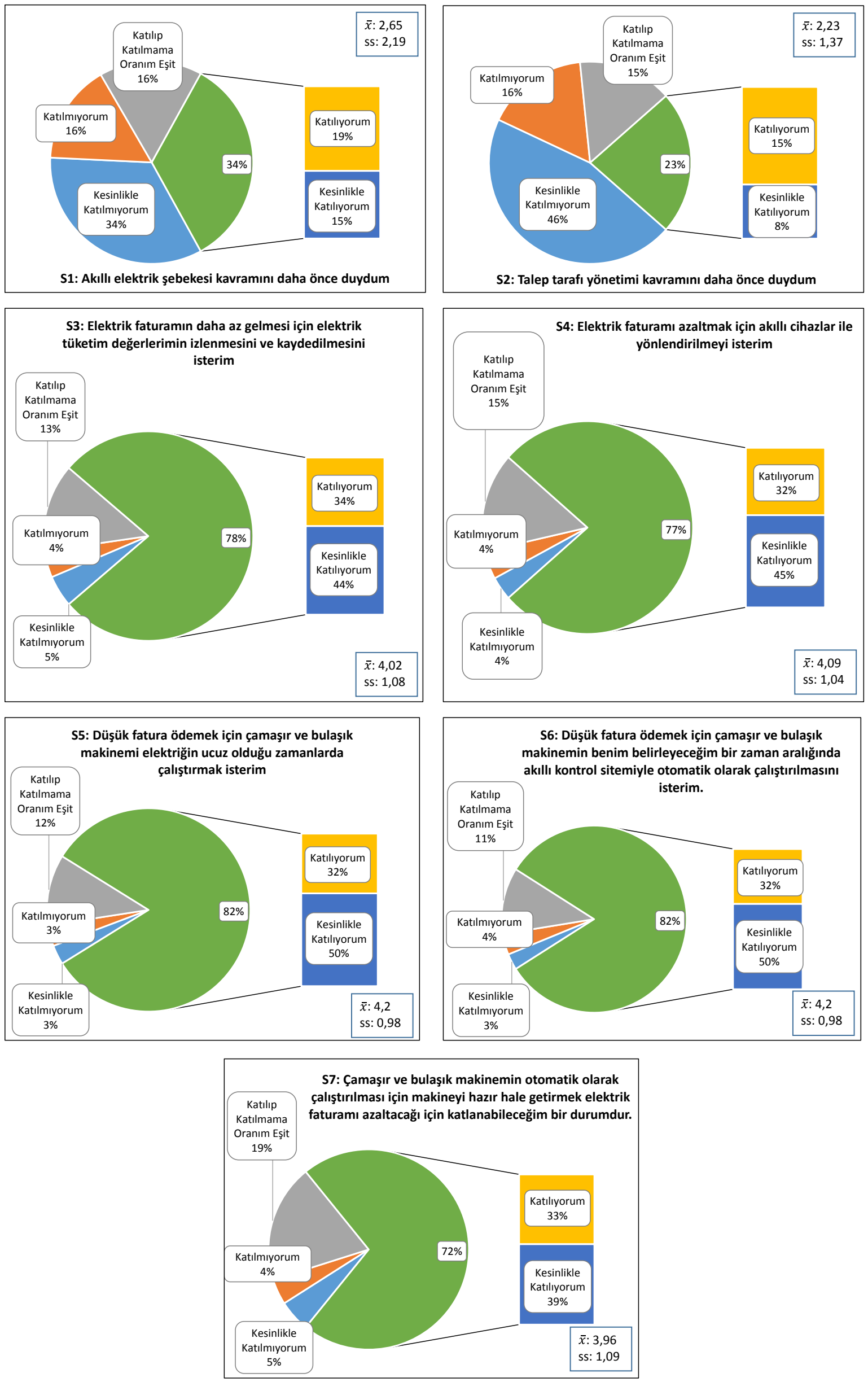

Şekil 10. Tüketicilerin ATYS ile ötelenebilir yüklerinin kontrolüne ilişkin tutumlarının analizi-1. 
Elektrik birim fiyatının ve elektrik faturalarının tüketicilerin çamaşır makinesi ve bulaşık makinesi gibi yüklerini ATYS ile kullanmalarına olan etkisini, tüketicilerin akıllı kontrol sistemini evlerinde kullanmayı düşünüp düşünmediklerini ve tüketicilerin akıllı kontrol sistemiyle planlama yapma davranışları konularında tüketicilerin tutumlarını tespit edebilmek için hazırlanan sorulara (S8-S13) alınan yanıtlara ait frekans analizleri Şekil 11'de verilmiştir.
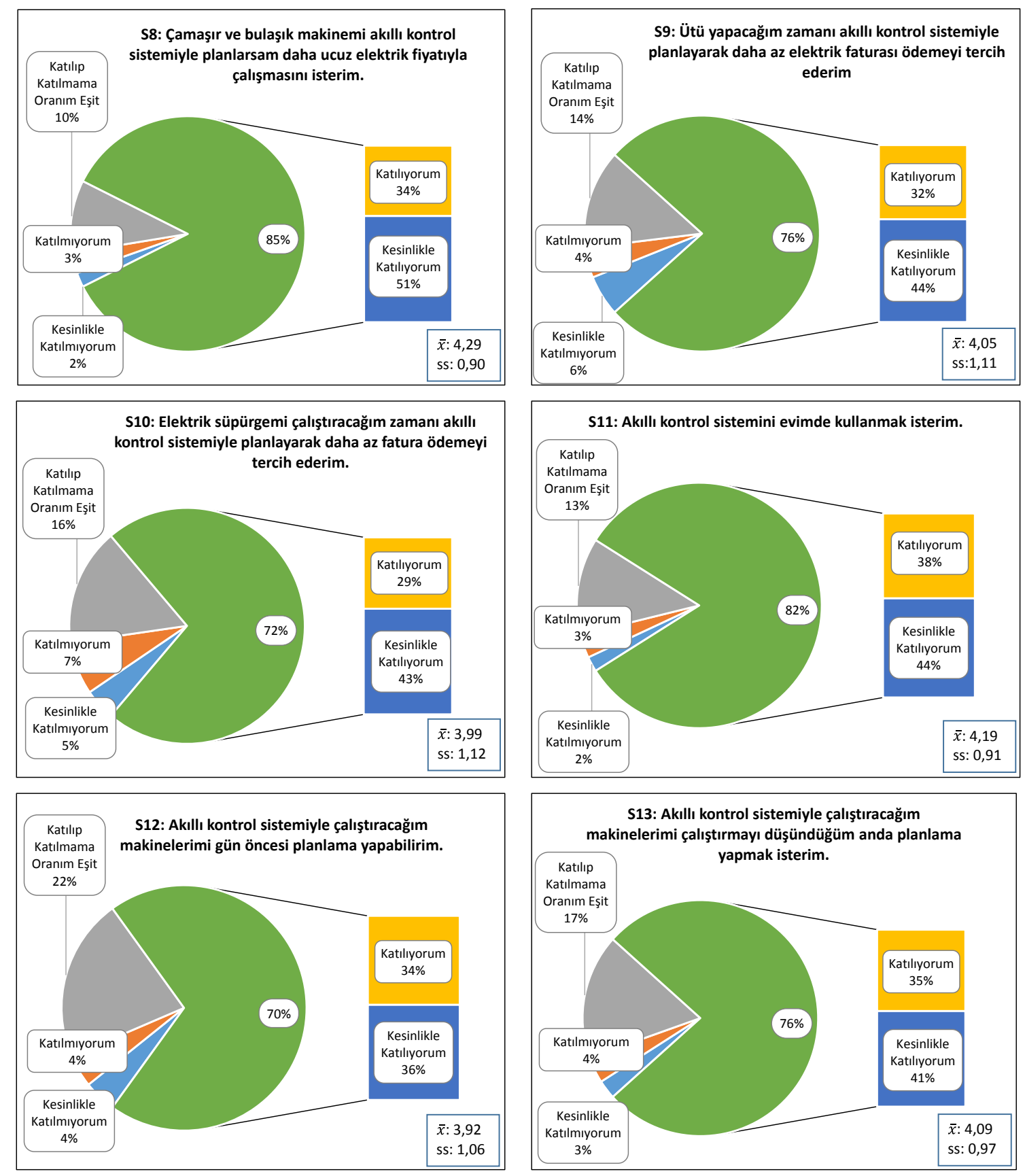

Şekil 11. Tüketicilerin ATYS ile ötelenebilir yüklerinin kontrolüne ilişkin tutumlarının analizi-2.

Ankete katılanların \%85'i (\%34 Katılıyorum, \%51 Kesinlikle Katılıyorum) çamaşır ve bulaşık makinelerini ATYS planladıklarında daha ucuz bir elektrik fiyatıyla faturalandırılmak isteğini belirtmiştir. Bu sorunun ütü ve elektrik süpürgesi için sorulan versiyonunda ise tüketicilerin olumlu 
tutumları sırasıly \%76 (\%32 Katılıyorum, \%44 Kesinlikle Katılıyorum) ve \%72 (\%29 Katılıorum, \%43 Kesinlikle Katıliyorum) olarak tespit edilmiştir. Ankete katılan tüketicilerin \%82'si (\%38 Katılıyorum, \%44 Kesinlikle Katıllyorum) akıllı kontrol sistemini evimde kullanmak isterim ifadesine olumlu bakmaktadırlar. "Akıllı kontrol sistemiyle çalıştıracağım makinelerimi gün öncesi planlama yapabilirim” ifadesi için tüketicilerin \%70’inin (\%34 Katılıyorum, \%36 Kesinlikle Katıllyorum) olumlu tutuma sahip olduğu görülmektedir. "Akıllı kontrol sistemiyle çalıştıracağım makinelerimi çalıştırmayı düşündüğüm anda planlama yapabilirim” ifadesine olumlu tutuma sahip tüketicilerin oranı ise \%76 (\%35 Katılıyorum, \%41 Kesinlikle Katıllyorum) olarak tespit edilmiştir.

Tüketicilerin Tablo 4'te verilen cihazlardan hangilerini ATYS'nin yönlendirmeleriyle kullanmak isteyebileceğine ilişkin seçimlik sorulara verdikleri cevapların frekansları Şekil 12'de sunulmuştur. Buna göre, soruya verilen yanıtlarda çamaşır makinesinin frekansı 297, elektrik süpürgesinin frekansı 126, ütünün frekansı 154, bulaşık makinesinin frekansı 269 olarak elde edilmiştir. Bu grafikte çamaşır kurutma makinesini işaretleyen kullanıcı sayısının 5 olduğunu görülmektedir. Bunun sebebi, ankete katılan tüketicilerin çok büyük bir kısmının evinde çamaşır kurutma makinesinin bulunmuyor olmasıdır.

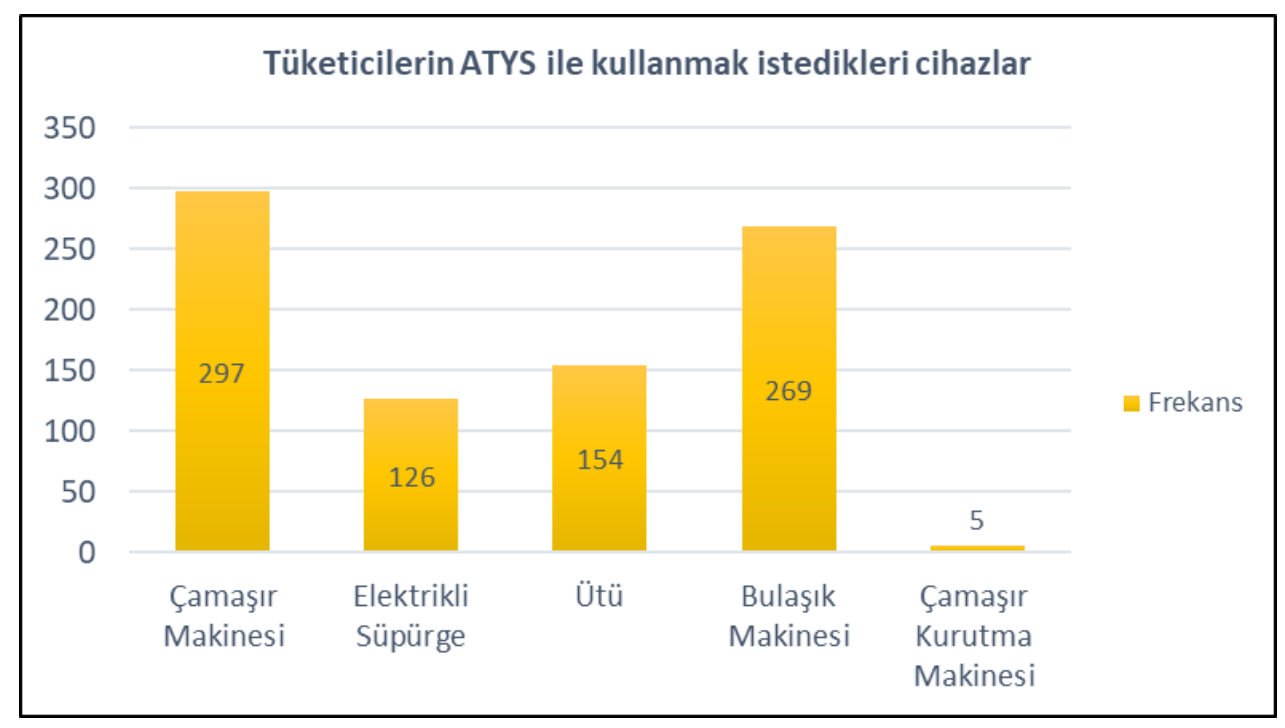

Şekil 12. Tüketicilerin ATYS ile kullanmak istedikleri cihazlara ait frekans analizi.

Tüketicilerin ötelenebilir yüklerini çalıştırma zamanlarına ait veri elde etmek için bir günün saatleri dörde bölünerek (06:01-12:00; 12:01-18:00; 18:01-23:59; 00:00-06:00) tüketicilere çamaşır makinesi, bulaşık makinesi, çamaşır kurutma makinesi, ütü ve elektrikli süpürge gibi yüksek güç tüketimine sahip yüklerini genellikle bu zaman dilimlerinin hangisinde/hangilerinde çalıştırdıkları Tablo 5'teki sorular aracılığıyla sorulmuştur. Elde edilen yanıtlara ait frekanslardan yola çıkarak oluşturulan grafikler Şekil 13’te verilmiştir. Grafikler incelendiğinde, özellikle bulaşık makinelerinin \%66’sının tüketimin tepe olduğu zaman diliminde (18:01-23:59) çalıştırıldığ1 görülmektedir. Elde edilen bulgulara göre, tepe tüketimlerin yaşandığı zaman diliminde çamaşır makinelerinin \%47si, 
ütülerin \%40’1, elektrikli süpürgelerin ise \%16’sı çalışmaktadır. Düşük tüketimlerin olduğu gece 00:00 ile sabah 06:00 arasında, yüksek güç tüketen bu cihazların çalıştırılma frekansları çamaşır ve bulaşık makineleri için \%9, ütüler için ise \%2 olarak tespit edilmiştir.
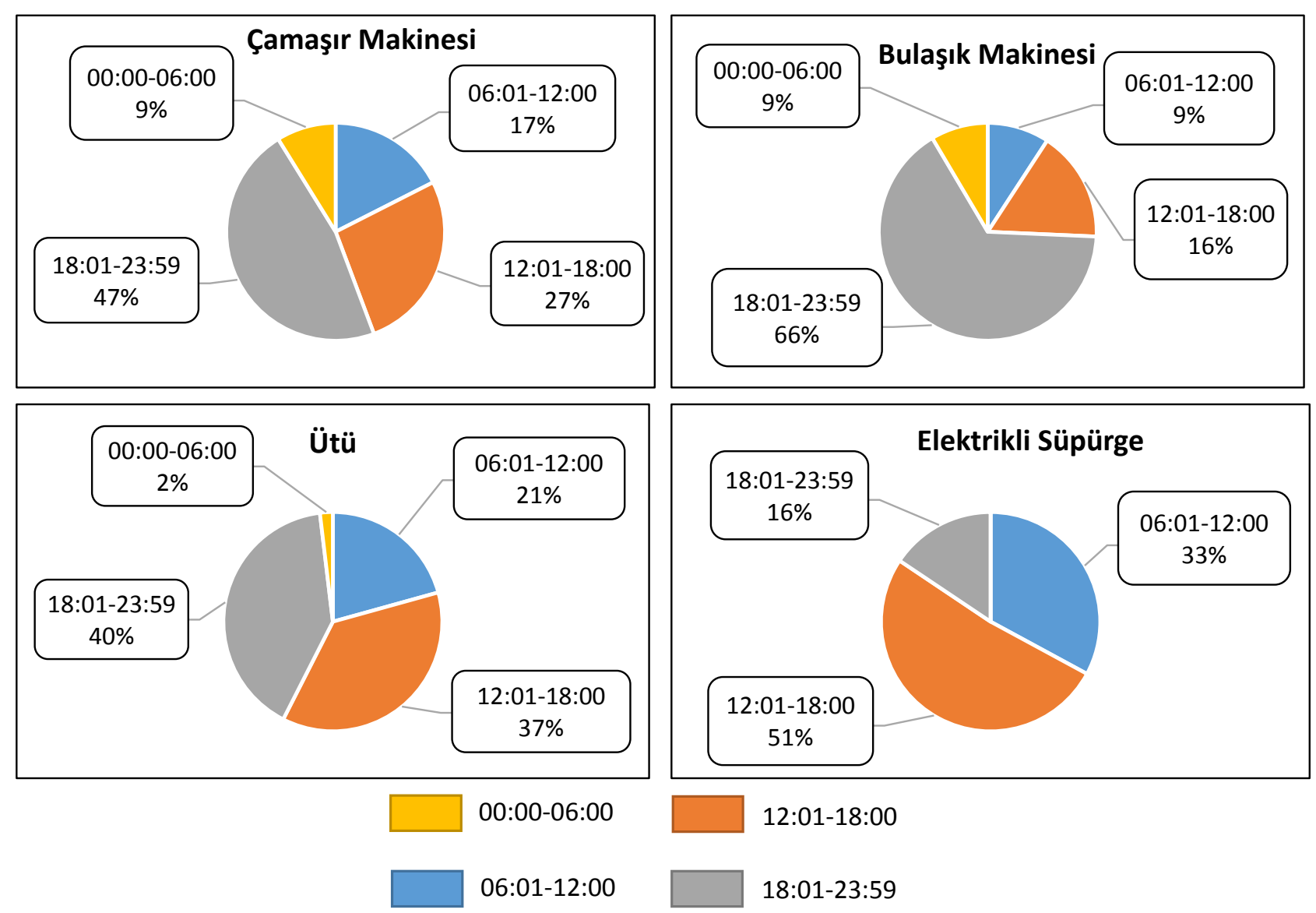

Şekil 13. Tüketicilerin bazı yüksek güç tüketen cihazlarını çalıştırdıkları zaman dilimleri

\section{Sonuçlar ve Öneriler}

Bu çalışmada Türkiye'de konutlarda yaşayan tüketicilerin ötelenebilir yüklerinin akıllı şebekelerde yük kaydırmaya dayalı talep tarafı yönetimi kapsamında kullanılmasına yönelik tutumlarını ölçmek ve tüketicilerin ötelenebilir yüklerinin kullanım alışkanlıklarına ait veri elde etmek için yapılan bir anket çalışmasından elde edilen bulgular aktarılmıştır. Anket sonuçları tüketicilerin akıllı talep yönetim sistemlerine ilişkin tutumlarının olumlu olduğunu göstermektedir. Anket sonuçlarına göre, tüketiciler ötelenebilir yüklerini gün öncesi planlama yapmaktansa, dinamik olarak planlama yapmayı öncelemektedirler. Bununla birlikte tüketiciler, akıllı talep yönetim sistemiyle planlayıp otomatik olarak çalıştırılmasını istediği cihazlarının genel elektrik fiyatından farklı, daha avantajlı bir fiyat ile faturalandırılmasına olumlu bakmaktadırlar. Bu sonuç, (Çakmak ve Altaş, 2020) çalışmasının tüketicilerde olumlu bir karşılığının bulunduğunu göstermektedir. 
Sonuç olarak, tüketicilerin ATYS sistemine ve akıllı şebekelerde yük kaydırmaya dayalı talep tarafı yönetimine olan bakış açılarını ölçmek için yapılan anket sonuçlarından elde edilen bulgular, ankete katılanların \%70'inden fazlasının tutumlarının olumlu (Katıliyorum ve Kesinlikle Katılıyorum) olduğunu göstermektedir. Burada tüketicilerin akıllı şebekelerde talep tarafı yönetimine tutumlarını olumlu yönde arttıracak olan iki faktörün mevcut olduğu söylenebilir. Bunlardan birincisi, tüketicilerin faturalarında elde edeceği indirim miktarıdır. İkinci önemli faktör ise, tüketicilerin ötelenebilir yüklerini ATYS ile kullanırken konfor düzeylerinin minimum şekilde etkilenmesidir. Bununla birlikte, tüketicilerin akıllı şebekelerde talep tarafı yönetimi konularında bilgilendirilmesi ve bu sistemlerin sağlayacağı olumlu katkılar konusunda tüketicilerde farkındalık yaratılması da önem arz etmektedir.

\section{Teşekkür}

Yazarlar anket çalışmasının hazırlık ve değerlendirme çalışmalarında desteklerini esirgemeyerek bilgi ve birikimleriyle vermiş oldukları katkılardan dolayı Prof. Dr. Ekrem CENGİZ'e, Doç. Dr. Salih YILDIZ’a ve Dr. Öğr. Üyesi Ersin DİKER'e teşekkür eder.

\section{Kaynaklar}

Akalın, M. (2015). Anket: örnek açıklamalarıly sosyal bilimlerde araştırma tekniği. Ankara: Seçkin Yayıncilik.

Altaş, İ. H., and Çakmak, R., (2020). A fuzzy decision maker to determine optimal starting time of shiftable loads in the smart grids. International Journal of Reasoning-based Intelligent Systems, 12(3), 210-216.

Altunışık, R., Coşkun, R., Bayraktaroğlu, S., ve Yıldırım, E., (2007). Sosyal bilimlerde araştırma yöntemleri. Sakarya: Sakarya Yayıncılık.

Arıkan, R. (2013). Anketler ve Anket Soruları. Ankara: Nobel Yayınları.

Back, A. K., Evens, C., Hukki, K., Manner, P., Niska, H., Pykälä, M. L., Saarenpää, J. and Similä, L., (2011). Consumer acceptability and adoption of Smart Grid. SGEM Research Report D1.2: Cleen Ltd.

Cardell, J., and Tabors, R., (1997). Operation and control in a competitive market: distributed generation in a restructured industry. The Energy Journal, International Association for Energy Economics, vol. 0 (Special I), pages 111-136.

Çakmak, R., and Altaş, İ. H. (2017, December). Optimal scheduling of time shiftable loads in a task scheduling based demand response program by symbiotic organisms search algorithm. 2017 Saudi Arabia Smart Grid (SASG 2017) (pp. 1-7). IEEE.

Çakmak, R., and Altaş, İ. H., (2020). A novel billing approach for fair and effective demand side management: Appliance level billing (AppLeBill). International Journal of Electrical Power \& Energy Systems, 121, 106062.

Çilingir, Z., ve Yıldız, S., (2010). Tüketicilerin Ürünlere Olan İlgileniminin Marka Sadakati Üzerindeki Etkisi: Sembolik Nitelikteki Bir Ürün Grubu İçin İstanbul İli Pilot Çalışması. Uluslararası Yönetim İktisat ve İsletme Dergisi, 6(11), 79-100.

Davito, B., Tai, H., and Uhlaner, R., (2010). The smart grid and the promise of demand-side management. McKinsey on Smart Grid, 3, 8-44.

Di Giorgio, A., \& Pimpinella, L., (2012). An event driven smart home controller enabling consumer economic saving and automated demand side management. Applied Energy, 96, 92-103. 
Gelazanskas, L., and Gamage, K. A., (2014). Demand side management in smart grid: A review and proposals for future direction. Sustainable Cities and Society, 11, 22-30.

Gellings, C. W. (1985). The concept of demand-side management for electric utilities. Proceedings of the IEEE, 73(10), 1468-1470.

IEA (International Energy Agency), (2016). World Energy Outlook 2016, IEA Publications, Paris, 2016.

Joshi, A., Kale, S., Chandel, S., and Pal, D. K. (2015). Likert Scale: Explored and Explained. Current Journal of Applied Science and Technology, 7(4), 396-403.

Liu, Y., Yuen, C., Huang, S., Hassan, N. U., Wang, X., \& Xie, S. (2014). Peak-to-average ratio constrained demand-side management with consumer's preference in residential smart grid. IEEE Journal of Selected Topics in Signal Processing, 8(6), 1084-1097.

Mert, W., Suschek-Berger, J., and Tritthart, W., (2008). Consumer acceptance of smart appliances. Smart domestic appliances in sustainable energy systems (Smart-A).

Mert, W., and Tritthart, W., (2009, November). Get smart! Consumer acceptance and restrictions of Smart Domestic Appliances in Sustainable Energy Systems. In TRANSPOSE Midterm Conference (pp.1-21). Institut für Politikwissenschaft der Westfälischen Wilhelms-Universität Münster.

Mohsenian-Rad, A. H., Wong, V. W., Jatskevich, J., Schober, R., and Leon-Garcia, A., (2010). Autonomous demand-side management based on game-theoretic energy consumption scheduling for the future smart grid. IEEE transactions on Smart Grid, 1(3), 320-331.

Moura, P. S., and De Almeida, A. T., (2010). The role of demand-side management in the grid integration of wind power. Applied Energy, 87(8), 2581-2588.

Oseni, M. O., Pollitt, M. G., Retner, D. M., Richter, L. L., Chyong, K., \& Baddeley, M., (2013). 2013 EPRG Public Opinion Survey: Smart Energy Survey-Attitudes and Behaviours (No. 1352). Faculty of Economics, University of Cambridge.

Park, E. S., Hwang, B., Ko, K., and Kim, D., (2017). Consumer acceptance analysis of the home energy management system. Sustainability, 9(12), 2351.

Shahnia, F., Wishart, M. T., Ghosh, A., Ledwich, G., and Zare, F., (2012). Smart demand side management of low-voltage distribution networks using multi-objective decision making. IET generation, transmission \& distribution, 6(10), 986-1000.

Spence, A., Demski, C., Butler, C., Parkhill, K., and Pidgeon, N. (2015). Public perceptions of demand-side management and a smarter energy future. Nature Climate Change, 5(6), 550-554.

Stadler, I. (2008). Power grid balancing of energy systems with high renewable energy penetration by demand response. Utilities Policy, 16(2), 90-98.

Uddin, M., Romlie, M. F., Abdullah, M. F., Abd Halim, S., and Kwang, T. C., (2018). A review on peak load shaving strategies. Renewable and Sustainable Energy Reviews, 82, 3323-3332.

Verbong, G. P., Beemsterboer, S., and Sengers, F., (2013). Smart grids or smart users? Involving users in developing a low carbon electricity economy. Energy policy, 52, 117-125.

Wissner, M. (2011). The Smart Grid-A saucerful of secrets?. Applied Energy, 88(7), 2509-2518.

$\mathrm{Xu}, \mathrm{T}$., and Taylor, P. C., (2008). Voltage control techniques for electrical distribution networks including distributed generation. IFAC Proceedings Volumes, 41(2), 11967-11971.

Yıldız, S., (2011). Elektronik hizmet marka değerini etkileyen faktörler: Elektronik hizmet müşterileri üzerine bir uygulama. Doktora Tezi, Karadeniz Teknik Üniversitesi, Sosyal Bilimler Enstitüsü. 